\title{
An Approach for Statistical Data Extraction from Photo Images of Pathological Biopsy Objects
}

\author{
Aleksandrs Sisojevs ${ }^{1,2}$, Katrina Bolochko ${ }^{2}$, Rihards Starinskis ${ }^{3}$, \\ ${ }^{1}$ Ventspils International Radio Astronomy Centre of VUC, ${ }^{2}$ Riga Technical University, ${ }^{3}$ Riga Stradiňs University
}

\begin{abstract}
The task of statistical data extraction from photo images of biomedical objects is important in biomedical diagnostics. For example, the analysis of photographic images of aortic valve taken after surgical operation can be used for further medical research. In this case, it is important to define the percentile correlation between the pathological and the macroscopically unchanged tissue. In this work, authors implement different methods for extracting the statistical data from images. The experimental results show the efficiency of the selected methods.
\end{abstract}

Keywords-Aortic valve, pattern recognition, segmentation, statistical data.

\section{INTRODUCTION}

The aortic valve (valva aortae) is part of the aortic root. The latter connects heart to the systemic circulation and plays major role in the function of heart and cardiovascular system. It also maintains optimal coronary perfusion and plays a role in the maintenance of a laminar flow in the vascular system. Each structure of the aortic root has its individual histological profile and anatomical architecture. The crown shape annulus, the three sinuses of Valsalva and interleaflet triangles, as well as the sinotubular junction, commissures and the aortic valve leaflets interact with each other in a certain way to maintain optimal function. This well-coordinated dynamic behavior has been shown to be of importance for specific flow characteristics, for coronary perfusion and left ventricular function [3].

Calcific aortic valve stenosis (CAVS) is an important clinical problem: $2.8 \%$ of adults aged over 75 have some degree of CAVS, and as many as $25 \%$ of adults aged over 65 have valvular sclerosis. Although risk factors and downstream mediators appear similar for CAVS and atherosclerosis (older age, male sex, hypertension, smoking, hypercholesterolemia, and diabetes) [2].

The histological changes of CAVS are inflammation extracellular matrix remodeling with increasing fibrosis, valve thickening, as well as angiogenesis and calcification [1].

Echocardiography is a key technique used to confirm the diagnosis of Valvular Heart Disease (VHD), as well as to assess its severity and prognosis. It should be performed and interpreted by properly trained personnel.
TABLE I

ECHOCARDIOGRAPHIC CRITERIA FOR THE DEFINITION OF SEVERE VALVE STENOSIS: AN INTEGRATIVE APPROACH

\begin{tabular}{|l|c|c|c|}
\hline & $\begin{array}{c}\text { Aortic } \\
\text { stenosis }\end{array}$ & $\begin{array}{c}\text { Mitral } \\
\text { stenosis }\end{array}$ & $\begin{array}{c}\text { Tricuspid } \\
\text { stenosis }\end{array}$ \\
\hline Valve area $\left(\mathrm{cm}^{2}\right)$ & $<1.0$ & $<1.0$ & - \\
\hline Indexed valve area $\left(\mathrm{cm}^{2} / \mathrm{m}^{2} \mathrm{BSA}\right)$ & $<0.6$ & - & - \\
\hline Mean gradient $(\mathrm{mmHg})$ & $>4.0 \mathrm{a}$ & $>10$ & $\geq 5$ \\
\hline Maximum jet velocity $(\mathrm{m} / \mathrm{s})$ & $>4.0 \mathrm{a}$ & - & - \\
\hline Velocity ratio & $<0.25$ & - & - \\
\hline
\end{tabular}

It is indicated with any patient with a murmur, unless no suspicion of valve disease is raised after the clinical evaluation. The evaluation of the severity of stenotic VHD should combine the assessment of valve area with flowdependent indices such as mean pressure gradient and maximal flow velocity (Table IV). Flow-dependent indices add further information and have prognostic value [4].

Without a doubt, a very important principle of diagnostics is the visualization of the aortic valve along with the analysis of echocardiogram's physiological parameters. The possibility to analyze the aortic valve at macro and micro levels only appears when extracting the valve during the prosthetics of aortic valve (exchange with an artificial valve) or autopsy (post-mortem examination). During these two processes, it is possible to examine the valve and analyze the distribution of pathological tissue. For these purposes, the Fix-Hodges method [5], [6] seems efficient, since we obtain specific data that can be used for defining the correlation between pathological tissue and echocardiogram's parameters. The obtained information can be used for solving the opposite task - using the parameters of the echocardiogram. It is possible to recreate the model of the aortic valve stenosis, which allows to assess the volume of pathological tissue without surgical invasion. Several medical aspects of this task are described in [11].

In the end, we obtain another parameter for defining the necessity and urgency of a surgical operation and for assessing the severity of patient's condition.

\section{IMPLEMENTED METHODS}

In order to solve the task of image segmentation methods of object recognition (classification) are used in this work. 
Objects of classification are sets of image pixels, described in the RGB color system

$$
A_{i}=\left(\begin{array}{lll}
R_{i} & G_{i} & B_{i}
\end{array}\right)
$$

Two methods of object recognition were used: "Template Matching" and " $k$ Nearest-Neighbors" method (or "FixHodges method" [5], [6]). Let us examine both methods in detail.

\section{A. Method "Template Matching"}

The method "Template Matching" [7], [8] is a classification method, but in this work it was used to solve the task of image segmentation. The geometric interpretation of the method used for the task of segmentation is described in Fig. 1.

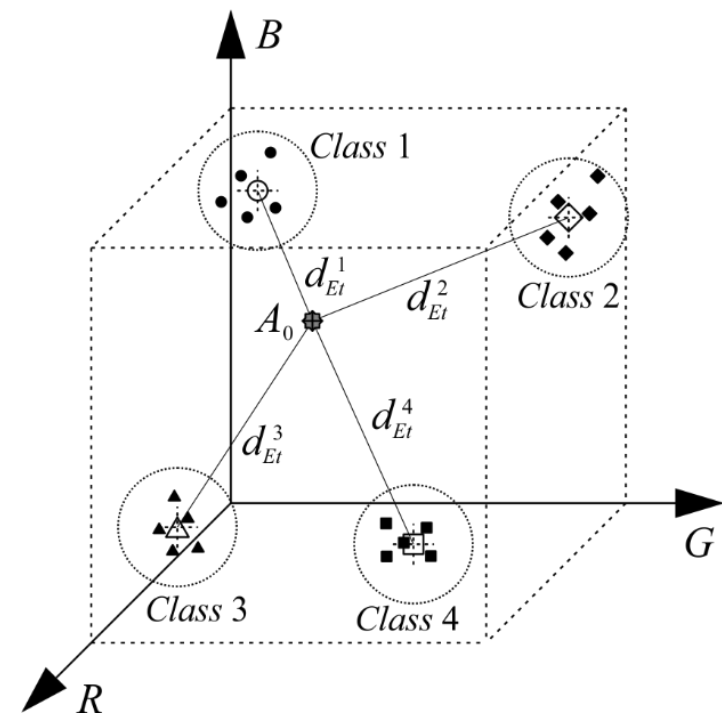

Fig. 1. Geometric interpretation of "Template Matching" method.

The method consists of the following steps:

In the beginning, templates ("centers of gravity") for each class are calculated using the learning set (objects, which are a priori known to belong to a specific class).

$$
A_{E t}^{p}=\left\{\begin{array}{l}
R_{E t}^{p}=\frac{1}{n} \sum_{i=1}^{n} R_{i}^{p} \\
G_{E t}^{p}=\frac{1}{n} \sum_{i=1}^{n} G_{i}^{p}, \\
B_{E t}^{p}=\frac{1}{n} \sum_{i=1}^{n} B_{i}^{p}
\end{array}\right.
$$

where:

$$
\begin{array}{ll}
R_{E t}^{p}, G_{E t}^{p}, B_{E t}^{p} & \text { template coordinates of class } p . \\
& p \text { class number; } \\
n & \text { number of objects in the current class; } \\
R_{i}^{p}, G_{i}^{p}, B_{i}^{p} & \text { coordinates of object } i \text { in class } p .
\end{array}
$$

Afterwards, a consecutive analysis is conducted for each pixel on the image, where the class affiliation for the pixel is unknown. For this, in each examined pixel $A_{0}$ distances (in RGB space) to all the templates are calculated:

$$
d_{E t}^{p}=\left|A_{0}-A_{E t}^{p}\right|
$$

where:

$$
\begin{array}{ll}
d_{E t}^{p} & \text { distance between objects; } \\
A_{0} & \text { examined object; } \\
A_{E t}^{p} & \text { template of class } p .
\end{array}
$$

The decision about affiliation of the examined object (pixel) $A_{0}$ to a specific class is made by finding the minimal distance to template $A_{E t}^{p}$, i.e. the object belongs to class $p$, if the distance between the template of this class and the examined object is minimal:

$$
\text { if }\left(d_{E t}^{p}=\min \left(d_{E t}^{0}, d_{E t}^{1}, \ldots\right)\right) \text { then } A_{0} \in \text { Class } p .
$$

Method "Template Matching" realizes the linear partition of the attribute space.

\section{B. Method "k Nearest-Neighbors"}

Method " $k$ Nearest-Neighbors" or Fix-Hodges method [9] and [10] is also a classification method, which in this work is used for the purpose of image segmentation. The geometric interpretation of the method as it was used in this work is illustrated in Fig. 2.

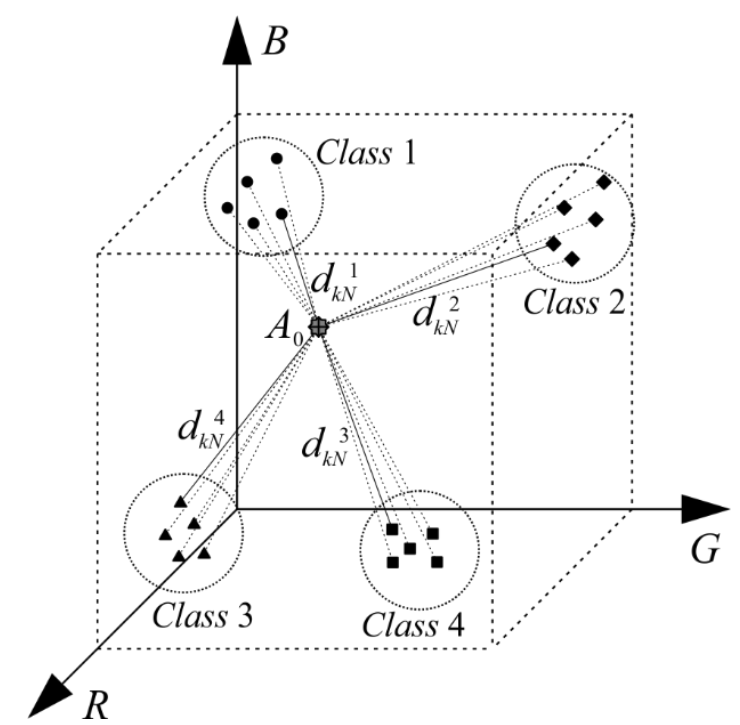

Fig. 2. Geometric interpretation of " $k$ Nearest-Neighbours" method.

When using this method, consecutive analysis is conducted for each image pixel, where class affiliation for the pixel is unknown. The method consists of the following steps:

In the beginning, distances (in RGB space) between the examined pixel and each object in the learning set are calculated:

$$
d_{i}^{p}=\left|A_{0}-A_{i}^{p}\right|
$$

where:

$A_{0} \quad$ examined object;

$A_{i}^{p} \quad$ object $i$ of class $p$

$p \quad$ class number;

$i \quad$ number of objects in class $p$.

Afterwards, in each class minimal distance to the examined object is calculated, for the examined object's nearest neighbor from the class objects is searched:

$$
d_{k N}^{p}=\min \left(d_{1}^{p}, d_{2}^{p}, \ldots\right) .
$$

The decision about the affiliation of the examined object (pixel) $A_{0}$ to the specific class is made by finding the minimal distance to the nearest neighbor in each class, i.e. the object 
belongs to class $p$ if one of its object's distance to the examined object is minimal:

$$
\text { if }\left(d_{k N}^{p}=\min \left(d_{k N}^{0}, d_{k N}^{1}, \ldots\right)\right) \text { then } A_{0} \in \text { Class } p .
$$

The " $k$ Nearest-Neighbors" method realizes piecewise linear partition of the attribute space, which allows using this method as the approximation of non-linear partition of attribute space.

\section{Used Distance Metrics}

As seen from equations (3) and (5) the methods of classification are based on using distances between objects in 3D space of RGB color system. Different metrics [12] can be used to calculate these distances. In this work, two existing metrics were used: Euclidean distance [12] and Manhattan distance [13], [14].

Let there be two points $A_{1}$ and $A_{2}$ in RGB color space. The coordinates of the points are calculated using equation (1). In this case, the distance between these two points when using Euclidean metric can be calculated as follows:

$$
d_{\text {Eucl }}=\sqrt{\left(R_{1}-R_{2}\right)^{2}+\left(G_{1}-G_{2}\right)^{2}+\left(B_{1}-B_{2}\right)^{2}} .
$$

When using the Manhattan metric, the distance between points $A_{1}$ and $A_{2}$ can be calculated using the following equation:

$$
d_{\text {Manh }}=\left|R_{1}-R_{2}\right|+\left|G_{1}-G_{2}\right|+\left|B_{1}-B_{2}\right| .
$$

The geometric interpretation of the said metrics is illustrated in Fig. 3.

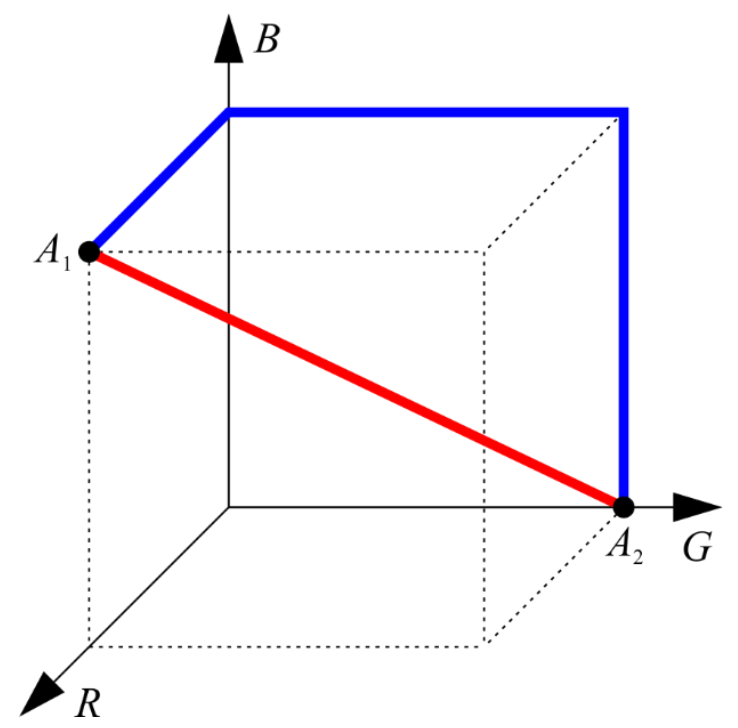

Fig. 3. Manhattan and Euclidean distances between two points.

Fig. 3 shows Euclidean distance between points $A_{1}$ and $A_{2}$ with a red line. One of the Manhattan distance variations is shown with a blue line.

\section{Method of Image Glare Removal}

In order to improve the results of image segmentation two methods of image quality enhancement were implemented in this work. The first method was used to remove the glare from the photographic image of the heart valve. The method uses the filtration-thresholding technique [15]. The image was processed with a $N \times M$ filter:

$$
\left[\begin{array}{ccc}
p_{0,0} & \cdots & p_{N, 0} \\
\vdots & \ddots & \vdots \\
p_{0, M} & \cdots & p_{N, M}
\end{array}\right] .
$$

The processing itself consisted of two steps. Firstly, all the pixels $p$ of the filter that had values (in RGB color space) below the threshold $T$ were saved to a special set $A$, which was used for creating a texture for replacing the glare.

$$
\text { if } p_{i, j}<T \text { then } p_{i, j} \in A \text {, }
$$

where $i \in[0 . . N], j \in[0 . . M]$.

Secondly, all the pixels $p$ of the filter that had values above the threshold $T$ were replaced by a random pixel from the set $A$.

$$
\text { if } p_{i, j}>T \text { then } p_{i, j}=\operatorname{random}(A) \text {, }
$$

where $i \in[0 . . N], j \in[0 . . M]$.

\section{E. Method of Noise Removal Using Median Filter}

The median method [16], [17] was used for noise removal. The method also processed the image with a $N \times M$ filter:

$$
\left[\begin{array}{ccc}
p_{0,0} & \cdots & p_{N, 0} \\
\vdots & \ddots & \vdots \\
p_{0, M} & \cdots & p_{N, M}
\end{array}\right] .
$$

The method consists of exchanging the filter's central pixel value by the calculated median value of the filter. This can be achieved by using the following equation:

$$
p_{\text {central }}=\frac{\sum_{i=0}^{N} \sum_{j=0}^{M} p_{i, j}}{N \cdot M} .
$$

Both of these image enhancement methods when used simultaneously are able to smooth the texture of the image and effectively remove the glare.

\section{EXPERIMENTAL RESULTS}

In this work statistical data were extracted from the photographic image of pathological biopsy using the following input data:

- 10 aortic heart valve photographs;

- 10 template segmentation images.

The input images are shown in the second column of Table VIII and Table X. The templates of segmented images are shown in the third column of Table VIII and Table X.

In order for the methods "Template Matching" and " $k$ Nearest-Neighbors" to work properly, it was necessary to use images of the start segments (segment map). An example of such a segment map for the input images (for the third object) is shown in Fig. 4. 


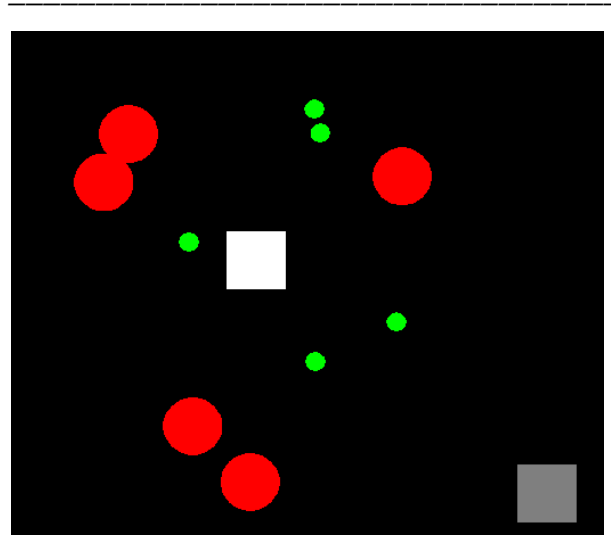

Fig. 4. The example of start segment's images.

The testing consisted of two parts. The first part was the segmentation of the 10 input images based on 10 segment maps (each input image had its own respective segment map). Each image was processed with two different segmentation methods using two different distance metrics (four experiments in total for each image).

The second part of the testing consisted of calculating the number pixels in the segmented regions of interest as well as the percentile correlation of these regions. In practice, two classes of segments were examined - the pathological tissue and the macroscopically unchanged tissue.

The first experiment was the segmentation of input images based on the segment map using method "Template Matching" with Euclidean metric. Statistical results are shown in Table II.

TABLE II

Statistical Data of Segmentation Using the “Template Matching” METHOD WITH EUCLIDEAN METRIC

\begin{tabular}{|c|c|c|c|c|c|}
\hline Object & \multicolumn{2}{|c|}{ Sample } & \multicolumn{3}{c|}{ Segmentation } \\
\hline$\#$ & $\begin{array}{c}\text { Class 1, } \\
\%\end{array}$ & $\begin{array}{c}\text { Class 2, } \\
\%\end{array}$ & $\begin{array}{c}\text { Cass 1, } \\
\%\end{array}$ & $\begin{array}{c}\text { Class 2, } \\
\%\end{array}$ & $\begin{array}{c}\text { Difference, } \\
\%\end{array}$ \\
\hline 1 & 68.985 & 31.015 & 64.804 & 35.196 & 4.181 \\
\hline 2 & 75.749 & 24.251 & 81.534 & 18.466 & 5.785 \\
\hline 3 & 79.279 & 20.721 & 73.512 & 26.488 & 5.767 \\
\hline 4 & 73.085 & 26.915 & 61.719 & 38.281 & 11.365 \\
\hline 5 & 23.718 & 76.282 & 37.336 & 62.664 & 13.618 \\
\hline 6 & 80.548 & 19.452 & 64.675 & 35.325 & 15.874 \\
\hline 7 & 63.879 & 36.121 & 46.186 & 53.814 & 17.693 \\
\hline 8 & 76.816 & 23.184 & 57.283 & 42.717 & 19.533 \\
\hline 9 & 83.948 & 16.052 & 62.373 & 37.627 & 21.575 \\
\hline 10 & 67.937 & 32.063 & 44.031 & 55.969 & 23.906 \\
\hline
\end{tabular}

As seen from Table II, the use of "Template Matching" method and Euclidean metric gave good results in terms of precision (less than $10 \%$ difference) only in 3 out of 10 objects $(30 \%)$. The second experiment performed on the images was the segmentation of input images based on the segment map using the "Template Matching" method with Manhattan metric. The input data was the same as in the first experiment. The statistical results for the second experiment are shown in Table III.
TABLE III

Statistical Data of Segmentation Using the “Template Matching” Method With ManhatTan Metric

\begin{tabular}{|c|c|c|c|c|c|}
\hline Object & \multicolumn{2}{|c|}{ Sample } & \multicolumn{3}{c|}{ Segmentation } \\
\hline$\#$ & $\begin{array}{c}\text { Class 1, } \\
\%\end{array}$ & $\begin{array}{c}\text { Class 2, } \\
\%\end{array}$ & $\begin{array}{c}\text { Class 1, } \\
\%\end{array}$ & $\begin{array}{c}\text { Class 2, } \\
\%\end{array}$ & $\begin{array}{c}\text { Difference, } \\
\%\end{array}$ \\
\hline 1 & 68.985 & 31.015 & 64.428 & 35.572 & 4.557 \\
\hline 2 & 75.749 & 24.251 & 80.962 & 19.038 & 5.213 \\
\hline 3 & 79.279 & 20.721 & 72.809 & 27.191 & 6.470 \\
\hline 4 & 73.085 & 26.915 & 62.333 & 37.667 & 10.752 \\
\hline 5 & 23.718 & 76.282 & 40.102 & 59.898 & 16.384 \\
\hline 6 & 80.548 & 19.452 & 64.632 & 35.368 & 15.916 \\
\hline 7 & 63.879 & 36.121 & 45.021 & 54.979 & 18.857 \\
\hline 8 & 76.816 & 23.184 & 58.019 & 41.981 & 18.796 \\
\hline 9 & 83.948 & 16.052 & 61.086 & 38.914 & 22.863 \\
\hline 10 & 67.937 & 32.063 & 44.594 & 55.406 & 23.343 \\
\hline
\end{tabular}

As seen in Table III, similarly to the first experiment, the use of "Template Matching" method and Manhattan metric gave good results in terms of precision (less than $10 \%$ difference) only in 3 out of 10 objects (30\%).

The fourth column in Table VIII and Table X shows the results of the "Template Matching" method, at the same time the tables show images that produced best statistical results based on the chosen metrics.

The third experiment performed on the images was the segmentation of input images based on the segment map using method " $k$ Nearest-Neighbors" with Euclidean metric. The input data was the same as in the first two experiments. The statistical results for the third experiment are shown in Table IV.

\section{TABLE IV}

STATISTICAL Data OF SEGMENTATION USING THE “ $K$ NEAREST-NEIGHBOR” METHOD WITH EUCLIDEAN METRIC

\begin{tabular}{|c|c|c|c|c|c|}
\hline Object & \multicolumn{2}{|c|}{ Sample } & \multicolumn{3}{c|}{ Segmentation } \\
\hline$\#$ & $\begin{array}{c}\text { Class 1, } \\
\%\end{array}$ & $\begin{array}{c}\text { Class 2, } \\
\%\end{array}$ & $\begin{array}{c}\text { Class 1, } \\
\%\end{array}$ & $\begin{array}{c}\text { Class 2, } \\
\%\end{array}$ & $\begin{array}{c}\text { Difference, } \\
\%\end{array}$ \\
\hline 1 & 68.985 & 31.015 & 72.208 & 27.792 & 3.223 \\
\hline 2 & 75.749 & 24.251 & 56.461 & 43.539 & 19.287 \\
\hline 3 & 79.279 & 20.721 & 82.397 & 17.603 & 3.118 \\
\hline 4 & 73.085 & 26.915 & 62.860 & 37.140 & 10.224 \\
\hline 5 & 23.718 & 76.282 & 26.824 & 73.176 & 3.106 \\
\hline 6 & 80.548 & 19.452 & 87.689 & 12.311 & 7.141 \\
\hline 7 & 63.879 & 36.121 & 77.022 & 22.978 & 13.144 \\
\hline 8 & 76.816 & 23.184 & 77.462 & 22.538 & 0.646 \\
\hline 9 & 83.948 & 16.052 & 83.227 & 16.773 & 0.722 \\
\hline 10 & 67.937 & 32.063 & 70.828 & 29.172 & 2.891 \\
\hline
\end{tabular}

As it can be seen in Table IV, the use of " $k$ NearestNeighbors" method and Euclidean metric gave good results in terms of precision (less than $10 \%$ difference), only in 7 out of 10 objects $(70 \%)$.

The fourth experiment performed on the images was the segmentation of input images based on the segment map using the method " $k$ Nearest-Neighbors" with Manhattan metric. The input data was the same as in the first three experiments. 
The statistical results for the fourth experiment are shown in Table V.

TABLE V

Statistical Data of Segmentation Using the “ $K$ NeAReSt-NeighboR" METHOD WiTh MANHATTAN METRIC

\begin{tabular}{|c|c|c|c|c|c|}
\hline Object & \multicolumn{2}{|c|}{ Sample } & \multicolumn{3}{c|}{ Segmentation } \\
\hline$\#$ & $\begin{array}{c}\text { Class 1, } \\
\%\end{array}$ & $\begin{array}{c}\text { Class 2, } \\
\%\end{array}$ & $\begin{array}{c}\text { Class 1, } \\
\%\end{array}$ & $\begin{array}{c}\text { Class 2, } \\
\%\end{array}$ & $\begin{array}{c}\text { Difference, } \\
\%\end{array}$ \\
\hline 1 & 68.985 & 31.015 & 72.727 & 27.273 & 3.742 \\
\hline 2 & 75.749 & 24.251 & 58.938 & 41.062 & 16.811 \\
\hline 3 & 79.279 & 20.721 & 82.843 & 17.157 & 3.564 \\
\hline 4 & 73.085 & 26.915 & 63.497 & 36.503 & 9.588 \\
\hline 5 & 23.718 & 76.282 & 26.735 & 73.265 & 3.017 \\
\hline 6 & 80.548 & 19.452 & 88.231 & 11.769 & 7.683 \\
\hline 7 & 63.879 & 36.121 & 78.185 & 21.815 & 14.307 \\
\hline 8 & 76.816 & 23.184 & 77.996 & 22.004 & 1.180 \\
\hline 9 & 83.948 & 16.052 & 83.643 & 16.357 & 0.306 \\
\hline 10 & 67.937 & 32.063 & 71.805 & 28.195 & 3.868 \\
\hline
\end{tabular}

As seen in Table V, the use of " $k$ Nearest-Neighbors" method and Manhattan metric gave good results in terms of precision (less than $10 \%$ difference) only in 8 out of 10 objects ( $80 \%$ ).

The fifth column in Table VIII and Table X shows the results of " $k$ Nearest-Neighbors" method, at the same time the tables show images that produced best statistical results based on the chosen metrics.

As seen from the experimental results, the "Template Matching" method outputs less precise results than the method of " $k$ Nearest-Neighbors". Based on these results only the method of " $k$ Nearest-Neighbors" was chosen for further experiments. Taking into account the results of the third and the fourth experiment, both metrics were examined.

In order to enhance the results of segmentation and the following statistical data extraction, image pre-processing was used in further experiments. The methods described in Section II-D, E were implemented to improve the quality of the input images. Taking into account the results of the last two experiments, 4 objects giving the worse statistical result were chosen for further experiments. These were objects 2, 4, 6 and 7 .

The fifth experiment was the segmentation of the preprocessed input images based on the sample segment maps using the method of " $k$ Nearest-Neighbors" and Euclidean metric. The starting segment map was the same as in previous four experiments. The statistical results for the fifth experiment are shown in Table VI.

TABLE VI

StATISTICAL DATA OF PRE-PROCESSED IMAGES SEGMENTATION USING THE “ $K$ NEAREST-NEIGHBOR” METHOD WITH EUCLIDEAN METRIC

\begin{tabular}{|c|c|c|c|c|}
\hline Object & \multicolumn{4}{|c|}{ Segmentation } \\
\hline$\#$ & $\begin{array}{c}\text { Class 1, } \\
\%\end{array}$ & $\begin{array}{c}\text { Class 2, } \\
\%\end{array}$ & $\begin{array}{c}\text { Difference from } \\
\text { the sample, } \%\end{array}$ & $\begin{array}{c}\text { Improvement, } \\
\%\end{array}$ \\
\hline 2 & 59.964 & 40.036 & 15.785 & 3.503 \\
\hline 4 & 62.876 & 37.124 & 10.209 & 0.016 \\
\hline 6 & 86.392 & 13.608 & 5.843 & 1.297 \\
\hline 7 & 74.796 & 25.204 & 10.918 & 2.226 \\
\hline
\end{tabular}

As seen in Table VI, implementation of the input image pre-processing methods and use of method " $k$ NearestNeighbors" and Euclidean metric provided minor improvement of statistical data (up to $3.5 \%$ ).

The sixth (and final) experiment was the segmentation of the pre-processed input images based on the sample segment maps using method " $k$ Nearest-Neighbors" and Manhattan metric. The starting segment map was the same as in previous five experiments. The statistical results for the sixth experiment are shown in Table VII.

\section{TABLE VII}

StATISTICAL DATA OF PRE-PROCESSED IMAGES SEGMENTATION USING THE “ $K$ NEAREST-NEIGHBOR” METHOD WITH MANHATTAN METRIC

\begin{tabular}{|c|c|c|c|c|}
\hline Object & \multicolumn{4}{|c|}{ Segmentation } \\
\hline$\#$ & $\begin{array}{c}\text { Class 1, } \\
\%\end{array}$ & $\begin{array}{c}\text { Class 2, } \\
\%\end{array}$ & $\begin{array}{c}\text { Difference } \\
\text { from the } \\
\text { sample, } \%\end{array}$ & $\begin{array}{c}\text { Improvement, } \\
\%\end{array}$ \\
\hline 2 & 61.066 & 38.934 & 14.683 & 2.128 \\
\hline 4 & 64.232 & 35.768 & 8.853 & 0.735 \\
\hline 6 & 87.354 & 12.646 & 6.805 & 0.877 \\
\hline 7 & 76.482 & 23.518 & 12.604 & 1.703 \\
\hline
\end{tabular}

As seen from Table VI, the implementation of the input image pre-processing methods and use of method " $k$ NearestNeighbors" and Manhattan metric provided minor improvement of statistical data (up to $2.13 \%$ ).

\section{RESULT AND CONCLUSION}

Several object recognition methods ("Template Matching" method and method of " $k$ Nearest-Neighbors") were implemented in this work in order to solve the task of image semi-automatic segmentation.

After a series of experiments it was concluded that method " $k$ Nearest-Neigbours" provides more precise results than the "Template matching" method.

It can also be noted that method " $k$ Nearest-Neighbors" requires more time for full segmentation (up to 7 minutes) when compared to "Template Matching" method (up to 4 seconds).

In order to improve the results of segmentation, two image quality enhancement methods were implemented (median filter and filtration-thresholding technique). This provided minor result improvement (up to $3.5 \%$ ).

A manual method of segmentation was also applied in order to obtain sample results for experiments.

\section{REFERENCES}

[1] K. Akat, M. Borggrefe, J. J. Kaden, "Aortic valve calcification: basic science to clinical practice," Heart, Vol. 95, no. 8, pp. 616-623, April, 2009. http://dx.doi.org/10.1136/hrt.2007.134783

[2] J. D. Miller, R. M. Weiss, D. D. Heistad, "Calcific Aortic Valve Stenosis: Methods, Models, and Mechanisms," Circ. Res. Vol. 108, no. 11 , pp. 1392-1412, May, 2011 http://dx.doi.org/10.1161/CIRCRESAHA.110.234138

[3] M. Misfeld, H.-H. Sievers, "Heart valve macro- and microstructure," Philosophical Transactions of the Royal Society B: Biological Sciences Vol. 362, no. 1484, pp. 1421-1436, Aug., 2007. http://dx.doi.org/10.1098/rstb.2007.2125

[4] A. Vahanian, O. Alfieri, F. Andreotti, M. J. Antunes et al. "Guidelines on the management of valvular heart disease: The Joint Task Force on the Management of Valvular Heart Disease of the European Society of 
Cardiology (ESC) and the European Association for Cardio-Thoracic Surgery (EACTS)," European Heart Journal, vol. 33, pp. 2451-2496, Aug., 2012. http://dx.doi.org/10.1093/eurheartj/ehs109

[5] E. Fix, J. L. Hodges, Jr., Discriminatory analysis, nonparametric discrimination: Consistency properties, International Statistical Review, vol. 57 no. 3, pp. 238-247, Dec., 1989. Reprint of original work from 1951. http://dx.doi.org/10.2307/1403797

[6] E. Fix, J. L. Hodges, Jr., Discriminatory analysis - nonparametric discrimination: small sample performance. Agrawala, A. K., Ed: Machine Recognition of Patterns, New York: IEEE press, pp. 280-322, 1977. Reprint of original work from 1952.

[7] R. O. Duda, P. E. Hart, D. G. Stork, in Pattern Classification, 2nd Edition, Wiley-Interscience, 2000, $680 \mathrm{p}$.

[8] N. J. Nilsson, in The Mathematical Foundations of Learning Machines, San Francisco: Morgan Kaufmann Pub, 1990, 138 p.

[9] E. A. Patrick, in Fundamentals of pattern recognition, $1^{\text {st }}$ ed. PrenticeHall, 1972, $504 \mathrm{p}$.

[10] T. M. Mitchell, in Machine Learning, McGraw-Hill Science, 1997, 414 p.

[11] R. Starinskis, V. Groma, A. Sisojevs, "Aortas vārstuḷa stenozes morfologiskā un datorizētā attēlu analīze," RSU XIX Morfologisko zinātnu konferences referätu tezes. - Rīga: Rīgas Stradiņa universitāte, pp. 38-39, 2014.

[12] D. R. Wilson, T. R. Martinez, "Improved Heterogeneous Distance Functions," Journal of Artificial Intelligence Research, vol. 6, pp. 1-34, 1997. http://dx.doi.org/10.1613/jair.346

[13] R. Euler, J. Sadek, "The $\pi \mathrm{s}$ Go Full Circle," Mathematics Magazine, vol. 72, no. 1, pp. 59-63, 1999.

[14] R. Jin, S. Wang, Y. Zhou, "Regularized Distance Metric Learning: Theory and Algorithm," Advances in Neural Information Processing Systems 22, pp. 862-870, 2009.

[15] L. G. Shapiro, G. C. Stockman, in Computer Vision, $1^{\text {st }}$ ed. NJ, USA: Prentice Hall, 2002, $580 \mathrm{p}$.

[16] W. K. Pratt, "Median filtering," in Semiannual Rep., Image Proc. Institute, University of Southern California, Sept. 1975, pp. 116-123, 1975
[17] T. Sun, M. Gabbouj, and Y. Neuvo, "Center Weighted Median Filters: Some Properties and Applications in Image Processing," Signal Processing Laboratory, vol. 35, no. 3, pp. 213-229, Feb. 1994. http://dx.doi.org/10.1016/0165-1684(94)90212-7

Aleksandrs Sisojevs was born in 1980. He is a Senior Researcher with Engineering Research Institute "Ventspils International Radio Astronomy centre" of Ventspils University College and a lecturer with the Image Processing and Computer Graphics Department, Faculty of Computer Science and Information Technology, Riga Technical University.

He received the degree of Bc. sc. ing. in 2001 and Dypl. ing. in 2003 from Riga Technical University and Mg. sc. comp. in 2006 from the University of Latvia and Dr. sc. ing. (IT) in 2011 from Riga Technical University.

His research interests include computer graphics, geometrical modelling and computer vision.

E-mail: Aleksandrs.Sisojevs@rtu.lv, alexiv@inbox.lv

Katrina Bolochko was born in 1985. She is an Assistant Professor at the Image Processing and Computer Graphics Department, Faculty of Computer Science and Information Technology, Riga Technical University.

She received the degree of $B c$. sc. ing. in 2005, Mg. sc. ing. in 2007 and Dr. sc. ing. (IT) in 2011 from Riga Technical University.

Her research interests include computer graphics, image processing and image analysis.

E-mail: Katrina.Bolocko@rtu.lv

Rihards Starinskis was born in 1992. He is a student at the Faculty of Medicine, Riga Stradin̄š University.

His research interests include cardiology, morphology and anatomical pathology.

E-mail: rihards9211@gmail.com

TABLE VIII

INPUT DATA AND RESULTS OF SEGMENTATION FOR OBJECTS 1-7

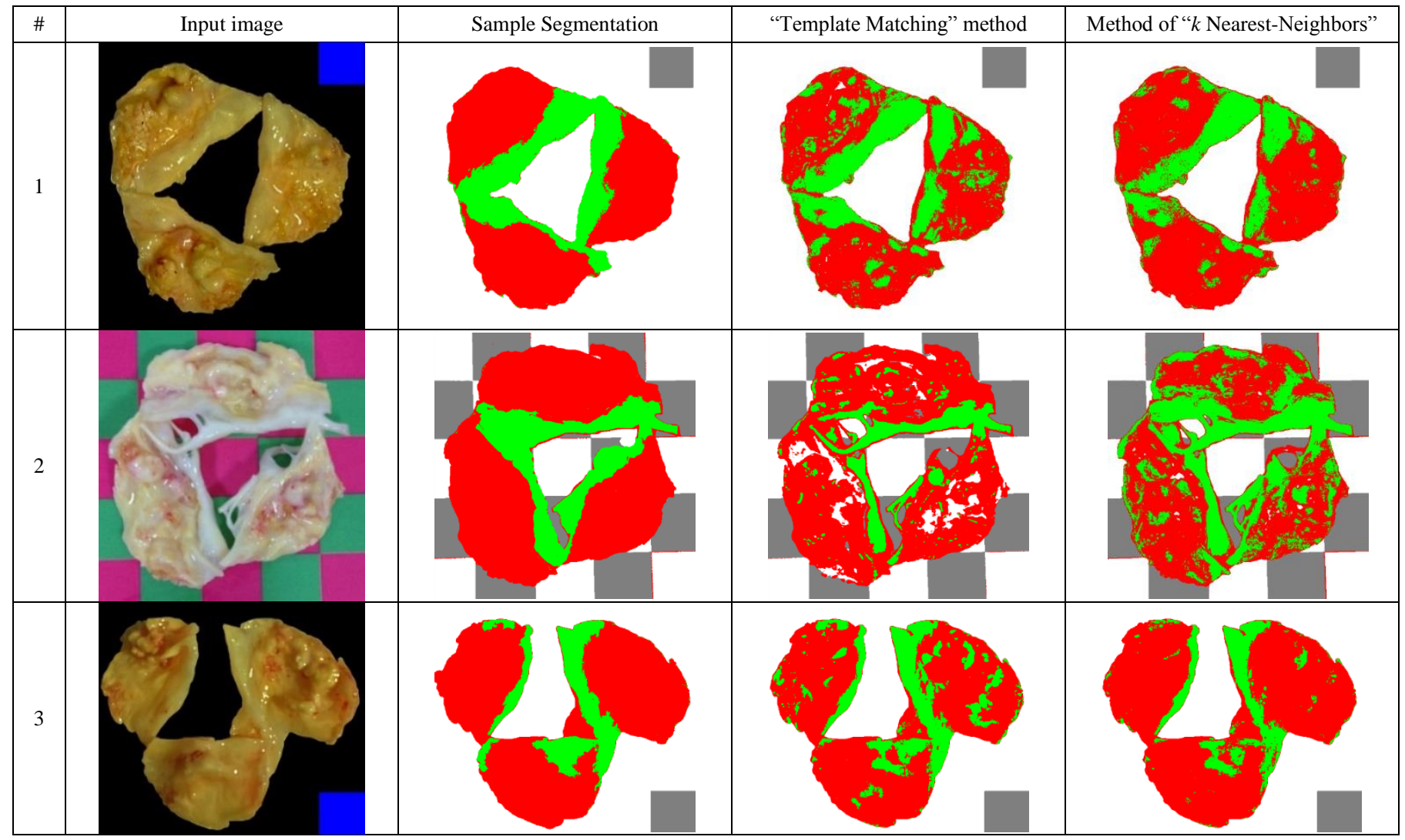




\begin{tabular}{|c|c|c|c|c|}
\hline Input image & Sample Segmentation & "Template Matching" method & Method of " $k$ Nearest-Neighbors" \\
\hline 4 & & & \\
\hline
\end{tabular}


TABLE IX

Results of SEgMENTATION AFTER IMAGE PRE-PROCESSING

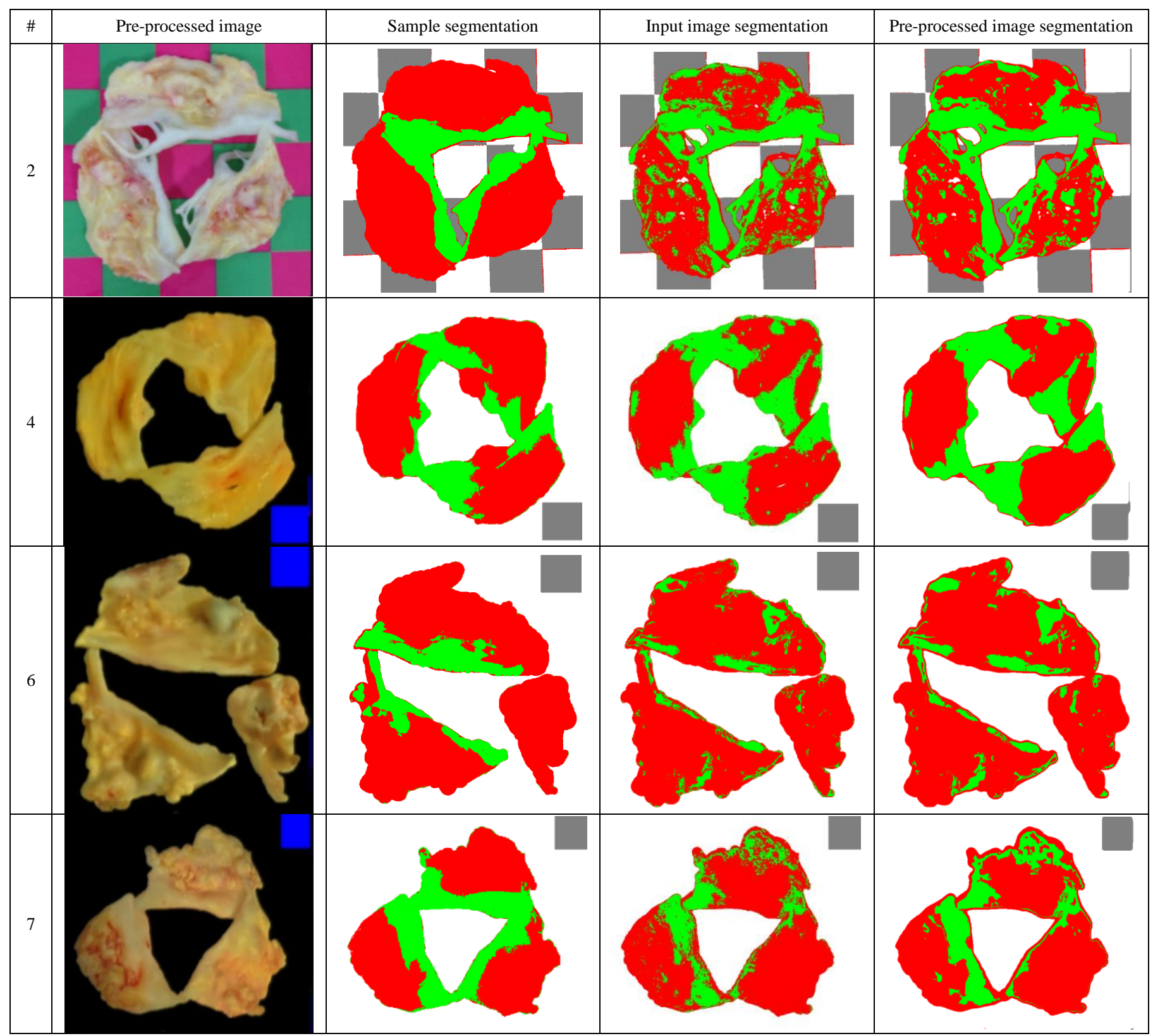


TABLE X

INPUT DATA AND RESUlTS OF SEGMENTATION FOR OBJECTS 8-10.

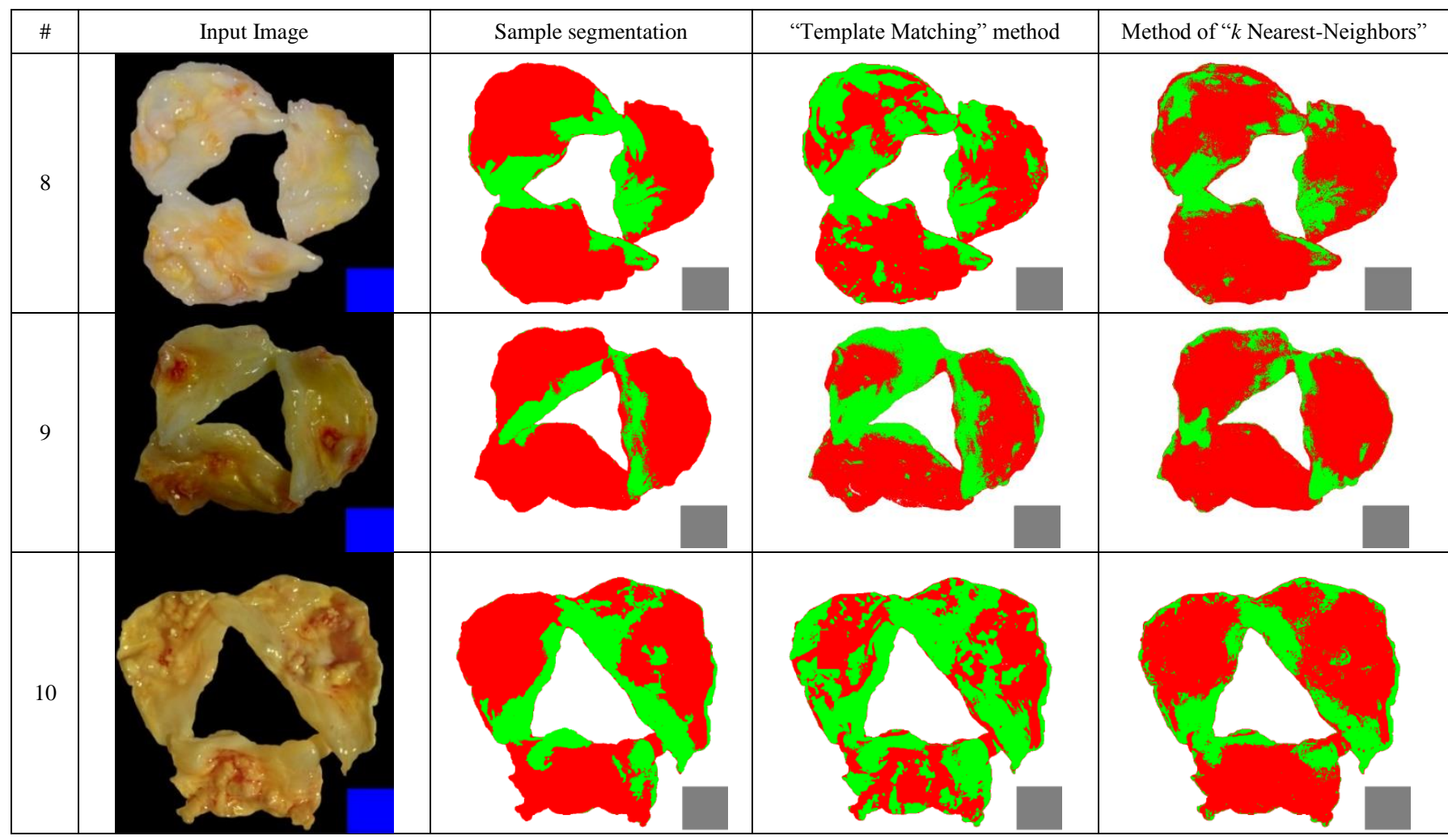

Aleksandrs Sisojevs, Katrina Boločko, Rihards Starinskis. Pieeja statistisko datu izdalī̌anai no patoloğisko biopsiju objektu fotoattēliem Skaitlisko statisko datu iegūšana no biomedicīnas objektu (piemēram, patoloǵiskās biopsijas materiāli) fotogrāfiskiem attēliem ir svarīgs un aktuāls uzdevums biomedicīnas diagnostikā.

Dotajā darbā tiek apskatīta statistisko datu iegūšana no aortas vārstuḷu (Valva aortae) fotogrāfiskiem attēliem, kas uzṇemti pēc kịurğiskām operācijām. Turpmākiem medicīniskiem pētījumiem (piemēram, aortas vārstuḷa stenozes diagnostikai) ir nepieciešams atrast procentuālu sakarību starp patologiskiem un makroskopiski neizmain̄itiem audiem. Dotajā darbā šī problēma tiek dalīta divos uzdevumos. Pirmais no tiem ir biomedicīnas objekta oriǵinālā fotoattēla segmentācija, lai izdalītu interešu reǵionus (region of interest) attēlā. Tiek veikta arī attēla pirmsapstrāde, ja tā ir nepieciešama. Nākamais uzdevums ir interešu reǵionu izmēru aprēḳināšana, lai noteiktu procentuālo sadalījumu patoloğiskiem un makroskopiski neizmainītiem audiem.

Segmentācijas uzdevuma risināšanai dotajā darbā tika izvēlētas divas tēlu atpazī̌sanas metodes "salīdzināšana ar etalonu" un " $k$-tuvāko kaimiṇu" metode, kā arī tika izmantotas divas metrikas - Eiklīda un Manhetena. Attēlu priekšapstrādei tika implementētas 2 metodes: pirmā samazina atspulgus fotoattēlā, bet otrā nogludina fotoattēlu ar mediāna filtra palīdzību. Visas metodes, kas aprakstītas dotajā darbā, bija realizētas praktiski, lai eksperimentāli noteiktu to efektivitāti izvirzītā uzdevuma risināšanā. Eksperimenti tika veikti ar 10 aortu vārstuḷu fotogrāfiskiem attēliem. Eksperimenti parādīja izvēlēto metožu efektivitāti praktiskā uzdevuma risināšanā (80 \% gadījumos segmentācijas rezultātu neprecizitāte, neizmantojot manuālo korekciju, bija mazāk par 10 \%).

Александр Сысоев, Катрина Болочко, Рихард Старинский. Подход извлечения статистических данных из фотоизображений объектов патологической биопсии.

Проблема извлечения численных статистических данных из фотографических изображений биомедицинских объектов (например, материалов патологической биопсии) является важной и актуальной практической задачей для медицинской диагностики. В данной работе рассматривается задача извлечения статистических данных из фотографических изображений аортальных клапанов (Valva aortae), извлеченнных из тела пациентов в результате хирургических операций. Для дальнейших медицинских исследований (например, диагностики стеноза аортального клапана) необходимо найти процентное соотношение между патологическими и макроскопически не изменёнными тканями. В данной работе эта проблема разделена на две задачи. Первая - сегментация исходного фотоизображения биомедицинского объекта (при необходимости производится так же предварительная обработка изображения) с целью выделения интересующих областей на изображении. Следующей задачей является подсчет размера интересующих сегментов с последующим расчётом процентного соотношения интересующих зон.

Для решения задачи сегментации в данной работе выбраны два метода распознавания образов: “сравнение с эталоном” и “ $K$-ближайших соседей” с использованием двух метрик - Евклидовой и Манхеттеновской. Для предварительной обработки изображений использованы два метода. Первый из них осуществляет минимизацию бликов на изображении объекта, и второй - осуществляет сглаживание исходного изображения с помощью метода медианного фильтра. В рамках работы все описаные методы были реализованы для проверки их эффективтности в решении поставленной задачи на примере 10 фотографических изображений аортального клапана. Результаты проведённых экспериментов показали эффективность выбранных методов в решении практической задачи (в $80 \%$ случаев результаты сегментации без мануальной коррекции давали погрешность менее $10 \%$ ). 